\title{
Community-Based Family Literacy Program: Comparing Different Durations and Family Characteristics
}

\author{
YaeBin Kim and Teresa Byington \\ University of Nevada, Reno/Cooperative Extension, Reno, NV, USA \\ Correspondence should be addressed to YaeBin Kim; yaek@unr.edu
}

Received 28 April 2016; Revised 22 August 2016; Accepted 24 August 2016

Academic Editor: Elena Nicoladis

Copyright ( $) 2016$ Y. Kim and T. Byington. This is an open access article distributed under the Creative Commons Attribution License, which permits unrestricted use, distribution, and reproduction in any medium, provided the original work is properly cited.

\begin{abstract}
The current study investigated the influence of the community-based family literacy program on parent's and children's engagement in family reading practices and language/literacy activities at home. Parent's and children's engagement in family reading practices and language/literacy activities based on different family characteristics and the lengths of program attended were compared. Six-week and four-week Family Storyteller Program for Preschoolers series were taught between 2013 and 2015. Three hundred seventy-five parents completed both presurveys and postsurveys. Parents showed promising results in enhancing parents' and child's engagement in family reading practices and language/literacy activities at home after participating in the intervention. It was also found that durations of the program and family characteristics were correlated to different outcomes.
\end{abstract}

\section{Introduction}

Children's literacy development begins at birth as babies hear language and begin to understand meaning from the spoken word. Young children's language and literacy abilities develop rapidly during the first five years of life. It has been determined that the level of exposure to language and literacy during the early years influences children's language and literacy development $[1,2]$. Differences in developing literacy skills can influence children's later academic success and competence as adults $[1,2]$. Children who have not developed basic literacy skill by the time they enter school are 3 to 4 times more likely to drop out of school [3]. In contrast, the development of early language and literacy skills is a strong predictor of children's' later reading and academic success [4].

During the past three decades, researchers have found that families play important roles in improving children's early language and literacy skills [5-7]. There is a connection between family involvement (or lack of involvement) and the development of early language and literacy skills and future success in school $[8,9]$. A mother's literacy level is a significant predictor of a child's future success in school and adults with lower literacy skills are less likely to read to their children [3]. Families of limited socioeconomic status have been found to read less frequently to their children and have fewer books in the home [10]. Parents (the term "parents" includes key persons who play the central parenting role in a child's life. Throughout this paper wherever we refer to parents we mean mothers, fathers, caregivers including grandparents, and other adults with responsibility for caring for a child) that read to their children help them develop a positive attitude towards reading [11] and gain a strong language and literacy foundation before they enter school [12-14]. Children are more likely to improve their literacy skills with increased levels of family involvement in language and literacy [13]. Family involvement can also prevent future reading challenges [15]. Children who have books at home and parents who read to them have higher literacy skills than children who do not have literacy-rich home environments and parent engagement [16].

Involvement in community-based family literacy programs can enhance the literacy of the entire family $[8,17]$. Hannon [18] proposed a "cycle of literacy" model to describe family literacy programs. The premise is that children with low literacy skills have parents with lower literacy skills and by triggering parents desire to support their children's educational development, parents develop their own literacy skills [19]. Community-based family literacy programs have 
been shown to improve the basic skills of participating adults [19] and family literacy programs that included shared book reading were effective at increasing preschoolers' emergent language and literacy skills [20]. Froiland et al. [21] found a positive association between parent education, number of books in the home, and the frequency of shared reading with preschool children. Therefore, family involvement is essential to promoting children's literacy development.

Bronfenbrenner recognized the family as an important focus for intervention [22]. According to the Ecological Systems Theory [23], human development occurs when interaction takes place within and among contexts such as family, school, and work. There is a need for multiple contexts supporting the development of a child. Neighborhood factors are one of those multiple contexts that have been linked to family literacy and early literacy achievement. Bronfenbrenner's theory serves as a fundamental rationale for family literacy programs because these types of programs focus on family life and parents' facilitation of emergent literacy within their neighborhood which is the context of the families' development. Neighborhood parent social networks have been linked to family literacy and early literacy development [24]. Kohen and colleagues [25] had similar findings in Canada and determined links between neighborhood and literacy at home. Therefore, neighborhood-based family literacy programs have the potential to enhance early language and literacy development through family involvement in literacy activities at home and in the community.

Family literacy programs have been shown to have a positive effect on young children's language and literacy development $[26,27]$ into the elementary school years [28]. As stated earlier, these programs are effective in developing not only emergent language and literacy skills but also parents' literacy skills [29, 30]. According to a study reviewing 82 studies of family literacy programs [31], family literacy programs resulted in positive changes to children's literacy skills, enjoyment of reading, motivation to engage in literacy activities, and improvement in parent's parenting skills. Parents had higher levels of self-efficacy due to helping children be better readers and learners [9]. However, a meta-analysis of different types of reading interventions determined that only having parents read to their child (K-Grade 3) may not improve early reading acquisition, whereas teaching parents to tutor their children using specific reading activities was more effective [32]. Another study reviewing several studies about the efficacy of reading to preschoolers also found that the relationships between parent-preschooler reading and language and literacy abilities of children have varied across studies and most intervention programs have provided not only parent-child book reading but also books, guidance, and feedback, so it is hard to estimate what actually made the intervention effective [33].

There has been no consensus or evidence that the duration of program exposure makes any differences in program effects; however, longer programs may provide more opportunities for families to engage in reading and other types of literacy activities [34]. Providing programs of shorter length may also encourage more consistent participation, as parents of young children face many demands for their time. Therefore, the authors sought to determine whether shorter program length made any differences in participants' outcomes.

Social and racial differences can impact children's language and literacy skills [35-38]. Low-income African children had less developed emergent literacy skills relative to their white peers [38]. Children of mothers with higher education and income had higher emergent literacy outcomes [37]. Spanish-English bilingual preschoolers had lower early language and literacy outcomes than their Caucasian and Asian counterparts, even when controlling for other socioeconomic variables [39]. Family literacy programs provided at neighborhood schools have been shown to help teachers and school personnel gain a greater understanding of the cultural and linguistic diversity of families in their communities [40]. Therefore, family literacy programs are an effective intervention for promoting the development of children's and parent's language and literacy skills.

The main purpose of this study was to evaluate the influence of a community-based family literacy program on the frequency of parent's and children's engagement in family reading practices and language/literacy activities at home. In addition, parent's and children's engagement in family reading practices and language/literacy activities were compared based on different family characteristics and the lengths of program attended. It was expected that both parents and children would increase the frequency of engaging in reading and language related activities after participating in the intervention and that length of program participation would make a difference.

\section{Methods}

2.1. Intervention. In 2013, the University of Nevada, Reno, Cooperative Extension received funding through the Striving Readers Comprehensive Literacy Program (federally funded program) to provide community literacy programs to limited resource families with children of 0 to 5 years of age. The program was provided at public schools (parent centers or preschool programs), community child care centers, and Head Start programs. One of the interventions selected was the Family Storyteller Program for Preschoolers. This family literacy program is based on Bronfenbrenner's theory and was developed by faculty at University of Nevada, Cooperative Extension [41].

2.2. Family Storyteller Program for Preschoolers. The Family Storyteller Program features weekly 1-hour sessions attended by families and their preschool age child with a focus on shared reading and participation in other types of literacy activities. Each session features a children's book such as Goodnight Moon by Margaret Wise. At the beginning of each session, the instructor models book reading techniques such as previewing the book and asking children meaningful questions. Parents are taught specific reading and literacy activities to do with their child at home. Next, parents participate in shared reading as they read the featured book to their preschooler and then engage in a literacy activity related to the book. At the end of the session, families are given the 
book and a packet of supplemental activities to take home. The families attending the program were a combination of Spanish-speaking and English-speaking families. Program instruction was given in both English and Spanish. The families were given books and handouts in both English and Spanish. One of the objectives of this grant project was to give parents/caregivers more opportunities to practice English. Many of participants attending the program were encouraged by school district personnel to learn English as a second language.

One of the main features of the program was the involvement of both the parents and the children reading and doing activities together. The book-related activities included creating a Brown Bear felt board story, making a set of Hungry Caterpillar sequencing cards, and creating a Chef's hat for Wolf's Chicken Stew. During the program, families are encouraged to build their home libraries as they are given one book every week and to visit local libraries to check out additional books. The intervention was originally designed to have 6 weekly 1-hour sessions; however, due to high attrition rates during the first year of the study (and lower funding levels), the program length was shortened to 4 weeks during the second year.

In 2013-2014, the 6-week Family Storyteller series was taught 52 times. Among 6-week participants, 377 parents completed presurvey and 199 completed both presurvey and postsurvey (53\% completion rate). In 2014-2015, the 4-week Family Storyteller series was taught 26 times. Among 4week participants, 217 parents completed presurvey and 175 completed both presurvey and postsurvey $(81 \%$ completion rate). Following the second year of the study, the authors were interested in comparing the child and parent outcomes based on the different lengths of the program attended by the families completing the program.

2.3. Participants and Program Sites. The Family Storyteller Program for Preschoolers was taught in both English and Spanish by a bilingual instructor at elementary school, Head Start, and community child care sites in economically disadvantaged areas in an urban area of a southwestern state. Around sixty percent of participants' ethnicity was Hispanic and their native language was not English. More than half of the participants' household incomes were $\$ 20,000$ or less and about two-thirds of the participants were high school graduates or had less than a high school education (see Table 1).

2.4. Measures. A 17-item Family Reading Survey was adapted from a survey developed by Whitehurst [41] and then refined based on comments from school district personnel involved in the Striving Readers project. The Family Reading Survey was designed to assess family demographics and the reading and language practices (child and parent outcomes) of families participating in the Family Storyteller Program. The Family Reading Survey included seven items on family demographic information which included social service recipients, marital status, native language, ethnicity, parent's education level, household income, and first time to read to child (see Table 1). Ten items related to family reading practices such as how often a picture book was read to child. These items used a Likert scale from 1, hardly ever, to 4 , almost daily (see Table 2). Parents completed the survey during the first and last sessions of the Family Storyteller Program series.

2.5. Outcome Evaluation and Data Analysis. The Family Reading Survey was used to measure changes in the frequency of family reading and home-based language and literacy activities. Paired $t$-tests between presurvey and postsurvey were conducted to compare participant's responses. In addition, a two-way repeated measure ANCOVA was used to analyze differences in family reading practices based on the length of the program (4 weeks or 6 weeks) attended and family characteristics.

\section{Results}

3.1. Improvement in Family Reading Practices. Families attending two durations (4 weeks and 6 weeks) of the Family Storyteller Program demonstrated statistically significant improvement in parent's and children's voluntary engagement in reading and related activities (see Table 2). All parents reported that their children ask to be read to more often and looked at books by themselves more frequently. Children also participated in the following activities more often: drawing pictures, singing or reciting rhymes, telling stories, playing language and literacy games, and going to the library. Parents attending both series reported that they had more books at home (more than 21 books), spent at least 11 minutes reading with their child the day before the class, and read for themselves more than 11 minutes every day (see Figure 1).

\subsection{Family Reading Practices among Programs with Different} Durations. The literacy practices of families attending 4week and 6-week series were compared between presurvey and postsurvey. Repeated measure ANCOVA was performed to control for demographic variables when examining effects of different durations between pretest and posttest outcomes. Six-week participants showed statistically significant higher levels of parents' frequent engagement in activities when controlling for income $(F=11.29 ; p<.01$; see Figure 2$)$ and children's voluntary initiation of activities when controlling for education $(F=4.91 ; p<.05$; see Figure 3$)$. However, more 4 -week participants showed statistically significant increase in reading with children the day before they attended the class $(F=6.41 ; p<.05)$ when controlling for income (see Figure 4) and more of them had more than 21 books at posttest when controlling for native language $(F=6.06$; $p<$ .01 ; see Figure 5), ethnicity ( $F=22.55 ; p<.001$; see Figure 6 ), or first time to start reading to children $(F=6.06 ; p<.01$; see Figure 7).

\subsection{Family Reading Practices among Different Families.} The different characteristics (social service recipient, family income, marital status, native language, ethnicity, education, and first time to read to child) of families attending the two different series were compared between presurvey and postsurvey using repeated measure ANCOVA, controlling for two different durations ( 4 weeks and 6 weeks). Families with lower income showed more improvement in parents' frequent 
TABLE 1: Demographic characteristics of participants in family storyteller programs $(N=596)$.

\begin{tabular}{|c|c|c|c|c|}
\hline & \multicolumn{2}{|c|}{ 6-week $(n=377)$} & \multicolumn{2}{|c|}{ 4-week $(n=219)$} \\
\hline & Number & Percent & Number & Percent \\
\hline Social service recipients (WIC, TANF, Medicaid, and SNAP) & 217 & $62 \%$ & 131 & $64 \%$ \\
\hline \multicolumn{5}{|l|}{ Marital Status } \\
\hline Single & 76 & $20.2 \%$ & 65 & $29.7 \%$ \\
\hline Living with partner or married & 100 & $26.5 \%$ & 82 & $37.4 \%$ \\
\hline Married & 157 & $41.6 \%$ & 55 & $25.1 \%$ \\
\hline Prefer not to answer & 44 & $11.7 \%$ & 17 & $7.8 \%$ \\
\hline \multicolumn{5}{|l|}{ Native language } \\
\hline English & 76 & $20.2 \%$ & 62 & $28.3 \%$ \\
\hline Other languages & 258 & $68.4 \%$ & 142 & $64.8 \%$ \\
\hline Prefer not to answer & 43 & $11.4 \%$ & 15 & $6.8 \%$ \\
\hline \multicolumn{5}{|l|}{ Ethnicity } \\
\hline Hispanic & 270 & $71.6 \%$ & 140 & $63.9 \%$ \\
\hline Caucasian & 38 & $10.1 \%$ & 9 & $4.1 \%$ \\
\hline African American & 4 & $1.1 \%$ & 48 & $21.9 \%$ \\
\hline Asian & 6 & $1.6 \%$ & 4 & $1.8 \%$ \\
\hline Others & 34 & $9.0 \%$ & 3 & $1.4 \%$ \\
\hline Prefer not to answer & 25 & $6.6 \%$ & 15 & $6.8 \%$ \\
\hline \multicolumn{5}{|l|}{ Parent's education level } \\
\hline Less than ninth grade & 52 & $13.8 \%$ & 40 & $18.3 \%$ \\
\hline Some high school but did not finish & 71 & $18.8 \%$ & 51 & $23.3 \%$ \\
\hline High school graduate or GED & 92 & $24.4 \%$ & 81 & $37.0 \%$ \\
\hline High school + some college or trade school & 69 & $18.3 \%$ & 22 & $10.0 \%$ \\
\hline 2-Year associate degree & 13 & $3.4 \%$ & 3 & $1.4 \%$ \\
\hline 4-Year college & 5 & $3.7 \%$ & 2 & $0.9 \%$ \\
\hline Graduate school & 14 & $3.7 \%$ & 0 & 0 \\
\hline Prefer not to answer & 61 & $16.2 \%$ & 20 & $9.1 \%$ \\
\hline \multicolumn{5}{|l|}{ Household income } \\
\hline$\$ 0-\$ 10,000$ & 76 & $20.2 \%$ & 83 & $37.9 \%$ \\
\hline$\$ 10,001-\$ 20,000$ & 118 & $31.3 \%$ & 74 & $33.8 \%$ \\
\hline$\$ 20,001-\$ 40,000$ & 72 & $19.1 \%$ & 27 & $12.3 \%$ \\
\hline$\$ 40,001-\$ 80,000$ & 34 & $9.0 \%$ & 5 & $2.3 \%$ \\
\hline Over $\$ 80,001$ & 4 & $1.1 \%$ & 0 & 0 \\
\hline Prefer not to answer & 73 & $19.4 \%$ & 30 & $13.7 \%$ \\
\hline \multicolumn{5}{|l|}{ First time to read to child } \\
\hline Before 1 year & 123 & $32.6 \%$ & 58 & $26.5 \%$ \\
\hline $1-2$ years old & 134 & $35.5 \%$ & 115 & $52.5 \%$ \\
\hline After child's second birthday & 77 & $20.4 \%$ & 19 & $8.7 \%$ \\
\hline Prefer not to answer & 43 & $11.4 \%$ & 27 & $12.3 \%$ \\
\hline
\end{tabular}

engagement in activities even when controlling for durations $(F=11.29 ; p<.01$; see Figure 8$)$, but other variables did not make any difference. In addition, there was no difference in children's voluntary engagement in activities between pretest and posttest among different family characteristics when controlling for durations. More parents with lower income ( $F$ $=6.41 ; p<.05)$ or parents who started reading to children when their children were between 1 and 2 years old $(F=7.67$; $p<.01)$ showed statistically significant increase in minutes of reading with children the day before they attended the class (see Figures 9 and 10). Finally, more parents whose native language was not English reported having more than 21 books at posttest, even when controlling for durations $(F=4.45$; $p<.05$; see Figure 11).

\section{Discussion}

This study found that family literacy programs are efficacious in improving family and child reading and literacy practices as other previous studies have shown [8, 17, 20, 21, 31, 42]. The current study took a step further to investigate the role of different durations of the program and family characteristics. 
TABLE 2: Striving readers literacy program family storyteller program for preschoolers: frequency of family or child reading or language and literacy activities between before survey and after survey.

\begin{tabular}{|c|c|c|c|c|c|c|}
\hline \multirow{3}{*}{ Category } & \multicolumn{2}{|c|}{ 6-week $(n=199)$} & \multicolumn{4}{|c|}{ 4-week $(n=175)$} \\
\hline & Before survey & After survey & $t$ & Before survey & After survey & $t$ \\
\hline & $\mathrm{M}(\mathrm{SD})$ & $\mathrm{M}(\mathrm{SD})$ & & $\mathrm{M}(\mathrm{SD})$ & $\mathrm{M}(\mathrm{SD})$ & \\
\hline \multicolumn{7}{|l|}{ Indirect child outcomes } \\
\hline $\begin{array}{l}\text { How often does your child ask to be read } \\
\text { to? }\end{array}$ & $2.56(1.05)$ & $3.39(.69)$ & $9.35^{* * *}$ & $2.78(.85)$ & $3.48(.76)$ & $8.54^{* * *}$ \\
\hline $\begin{array}{l}\text { How often does your child look at books } \\
\text { by himself or herself? }\end{array}$ & $2.65(1.08)$ & $3.51(.62)$ & $9.64^{* * *}$ & $3.01(.75)$ & $3.63(.62)$ & $7.93^{* * *}$ \\
\hline How often does your child draw pictures? & $2.84(1.00)$ & $3.54(.63)$ & $8.80^{* * *}$ & $3.55(.70)$ & $3.70(.55)$ & $2.21^{*}$ \\
\hline \multicolumn{7}{|l|}{ Family outcomes } \\
\hline $\begin{array}{l}\text { How often do you or another family } \\
\text { member read a picture book with your } \\
\text { child? }\end{array}$ & $2.39(1.11)$ & $3.45(.69)$ & $11.33^{* * *}$ & $2.95(.74)$ & $3.50(.60)$ & $8.05^{* * *}$ \\
\hline $\begin{array}{l}\text { How often do you or another family } \\
\text { member sing or recite rhymes to your } \\
\text { child? }\end{array}$ & $2.38(.96)$ & $3.38(.80)$ & $11.44^{* * *}$ & $2.50(1.01)$ & $3.33(.80)$ & $8.96^{* * *}$ \\
\hline $\begin{array}{l}\text { How often do you or another family } \\
\text { member tell your child stories? }\end{array}$ & $2.47(.90)$ & $3.45(.72)$ & $12.33^{* * *}$ & $3.14(.89)$ & $3.64(.64)$ & $6.12^{* * *}$ \\
\hline $\begin{array}{l}\text { How often do you or another family } \\
\text { member play games with your child? }\end{array}$ & $2.18(1.03)$ & $3.42(.69)$ & $15.15^{* * *}$ & $2.48(.92)$ & $3.52(.68)$ & $12.75^{* * *}$ \\
\hline $\begin{array}{l}\text { How often do you go to the library with } \\
\text { your child? }\end{array}$ & $1.70(.84)$ & $2.81(1.10)$ & $11.89^{* * *}$ & $1.49(.77)$ & $2.45(.97)$ & $10.84^{* * *}$ \\
\hline
\end{tabular}

Note: scale ranging from 1 (hardly ever) to 4 (almost daily); ${ }^{* * *} p<.001$ and $^{*} p<.05$.

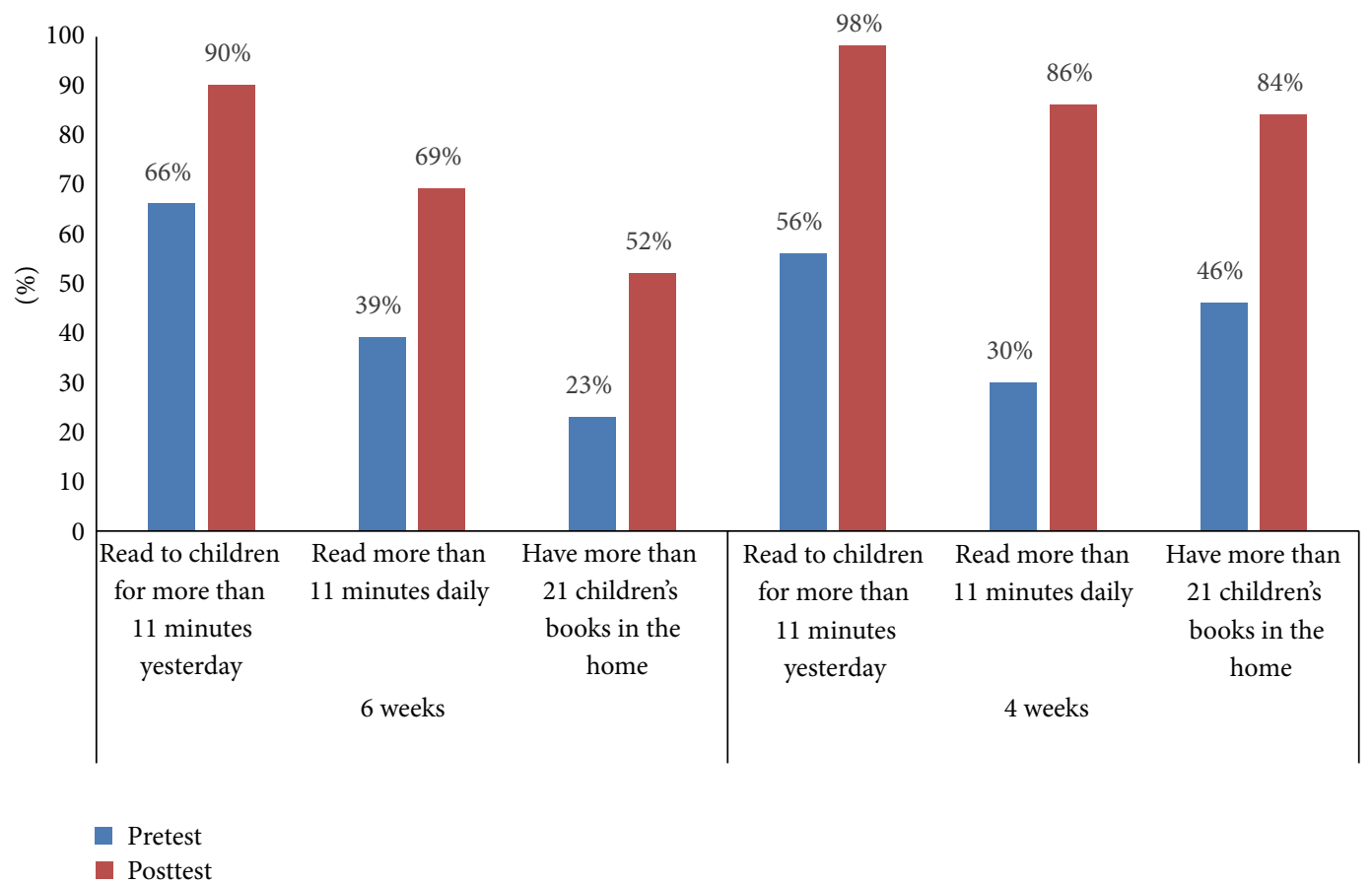

FIGURE 1: Duration of parents' reading to children and parents' own reading and number of books at home between pretest and posttest.

Six-week participants indicated a higher frequency of reading with children, telling stories, and going to the library when income was taken into account. Children of 6-week participants asked to be read to, looked at books by themselves, and drew pictures comparatively more often when parents' education was taken into account. However, 4-week participants seemed to read with children more than 11 minutes the day before the class and had more than 21 books at home when controlling for a few family characteristics (income, ethnicity, and native language). Likewise, families in 


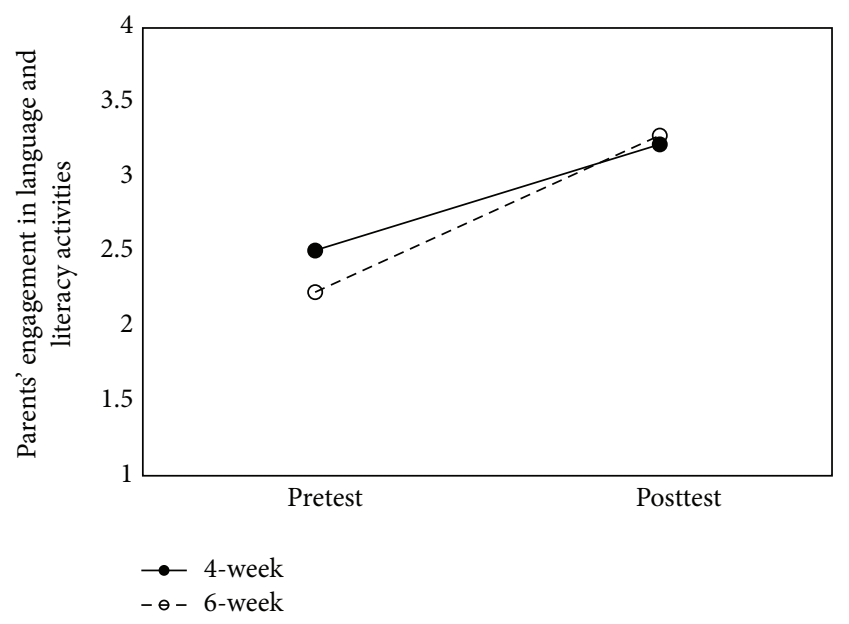

FIgURE 2: Estimated marginal means for parents' engagement in language and literacy activities between 4-week and 6-week participants across time with control of income.

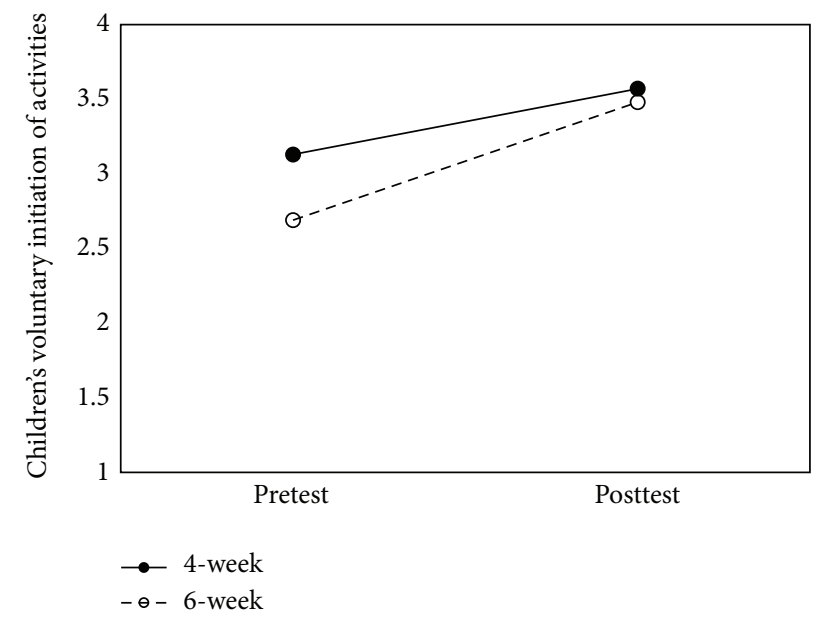

FIGURE 3: Estimated marginal means for children's voluntary initiation of activities between 4 -week and 6-week participants across time with control of parent's education.

a comprehensive early literacy project in a large urban school division in another state demonstrated significant positive changes in visiting libraries, parental attitudes about early literacy, and the number of books at home [42].

The participants of the 6-week program and 4-week program showed positive improvement in different outcomes. The outcomes from participants attending different durations of the programs were compared. As stated earlier, to mitigate attrition, a shorter 4 -week program was initiated in the second year and the completion rate rose from $53 \%$ to $81 \%$. The increase in completion may be due to families being able to make a shorter time commitment to the program as parents with young children face many demands on their time and energy.

Participants of the shorter program reported immediate changes such as increases in the frequency of reading the day before the class and the total number of children's books at home, whereas participants of the longer program reported

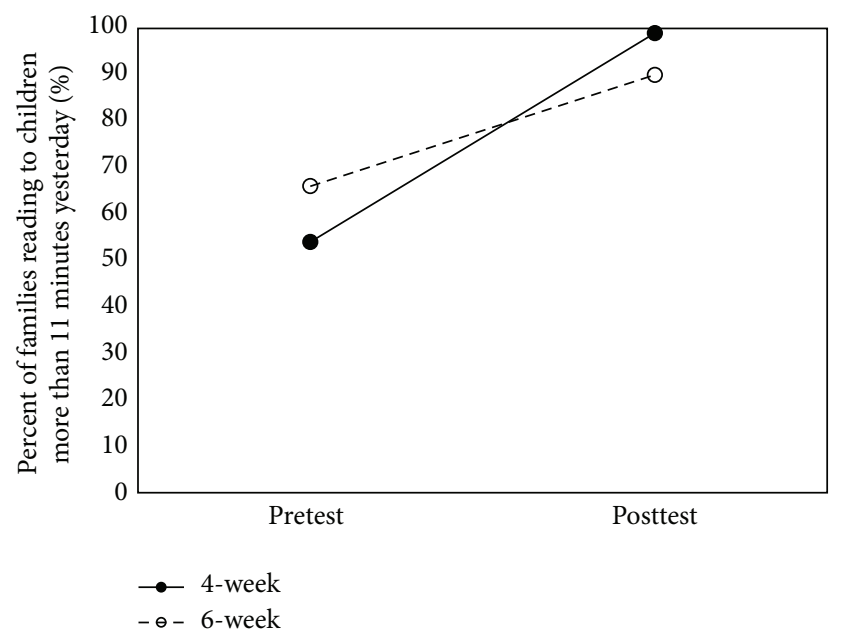

FIGURE 4: Estimated marginal means for families reading to children more than 11 minutes the day before the class between 4 -week and 6-week participants across time with control of income.

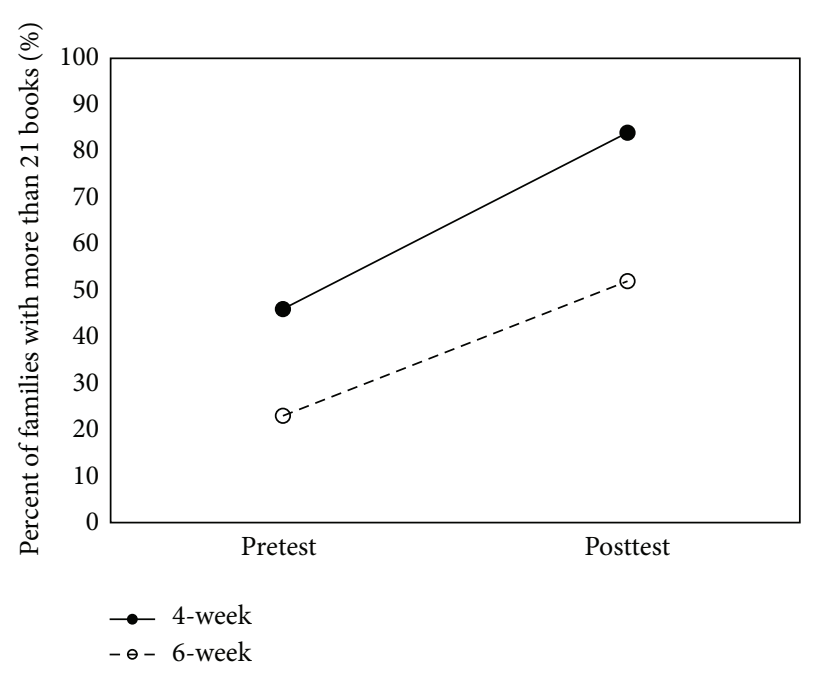

FIGURE 5: Estimated marginal means for families with more than 21 books between 4 -week and 6-week participants across time with control of native language.

engagement in activities such as going to the library, telling stories, singing, or reciting rhymes. As stated earlier in a study, duration of program exposure may not make any differences in program effects [34]. The question to ponder is whether the results of the 4-week program (with higher completion rates and immediate changes) are sufficient to recommend continuing to offer the program with shorter duration. In the future, it may be beneficial to offer the program with both time frames to match the individual needs of the families interested in participating. In addition, outcomes can be followed to see which program series helps families maintain positive family reading and literacy practices and improve children's language and literacy skills after completion of programs. Interestingly, regardless of the length of the program attended, certain family characteristics were related to particular family reading practices. 


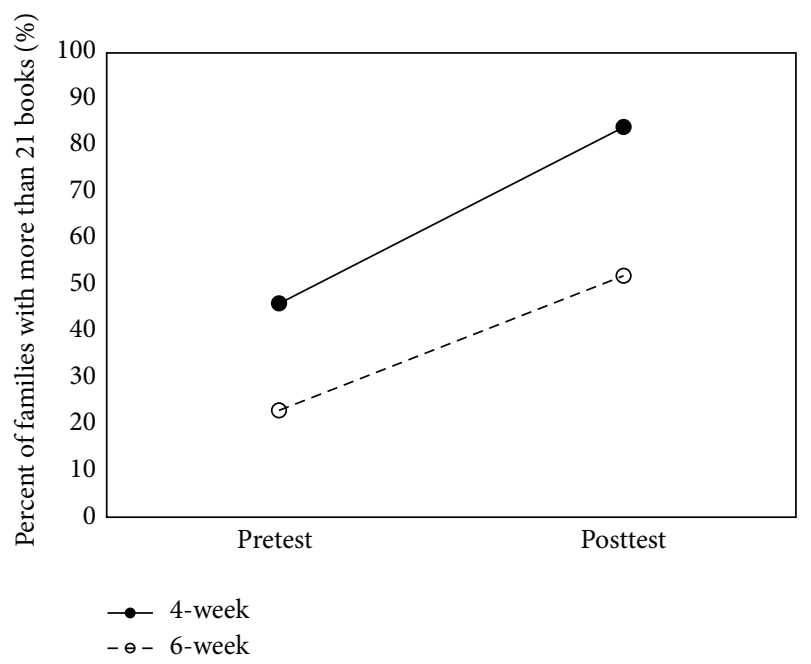

FIGURE 6: Estimated marginal means for families with more than 21 books between 4 -week and 6-week participants across time with control of ethnicity.

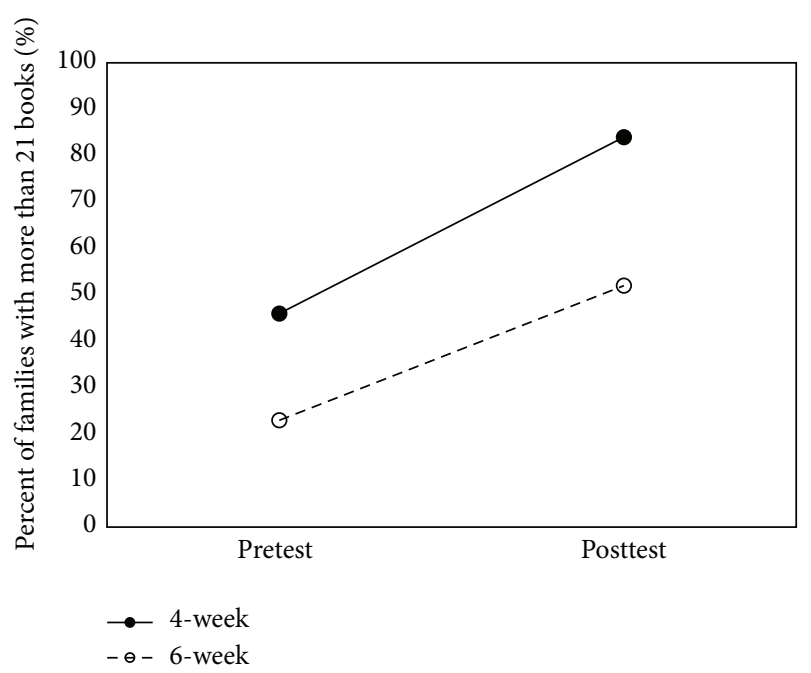

FIGURE 7: Estimated marginal means for families with more than 21 books between 4 -week and 6-week participants across time with control of first time to read to children.

Family characteristics did not influence changes in children's voluntary initiation of language and literacy activities such as children asking to be read to, looking at books by themselves, and drawing pictures. However, families with lower income showed more frequent parent's engagement in language and literacy activities. A previous study found that children of mothers with higher education and income had better emergent literacy outcomes [37]. However, the current study showed that parents from low-income families were engaged in language and literacy activities with children more often after attending the intervention program. Although the current study did not evaluate children's emergent literacy outcomes, parents' increased engagement in language and literacy activities is very positive when considering the fact that parents who read to their children help them develop

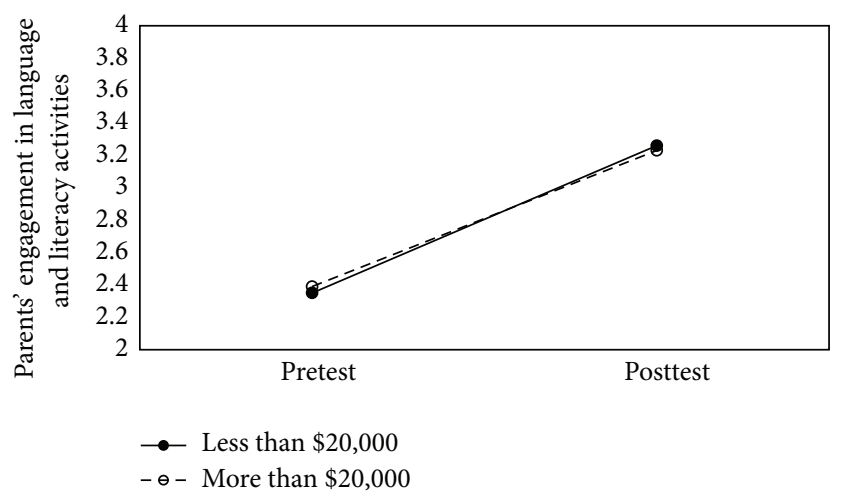

Figure 8: Estimated marginal means for parents' engagement in language and literacy activities between different income groups across time with control of durations.

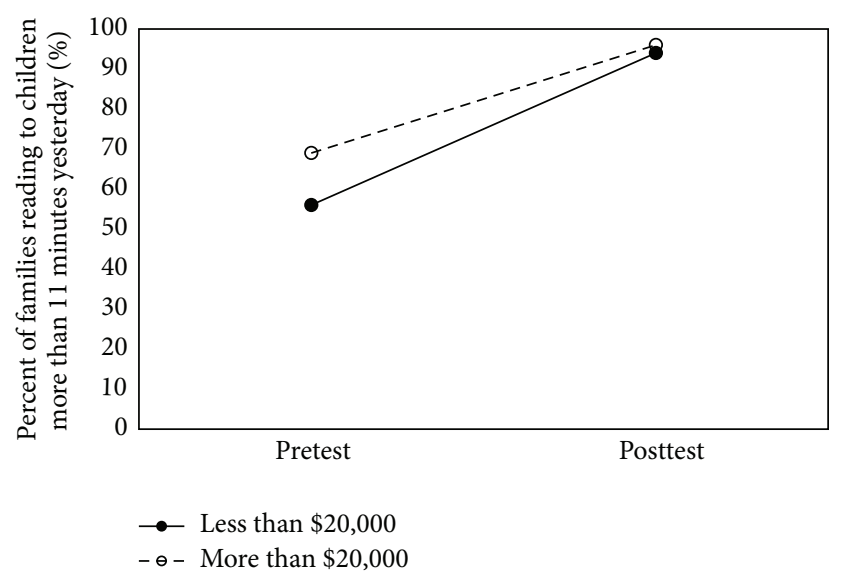

FIGURE 9: Estimated marginal means for percent of families reading to children more than 11 minutes the day before the class between different income groups across time with control of durations.

a positive attitude towards reading [11] and gain a strong language and literacy foundation before they enter school [12-14].

Families with lower income or parents who started reading to children when their children were between 1 and 2 years old tended to report that they read more than 11 minutes the day before the class. At the end of the program, parents whose native language was not English reported having more books than their counterparts. This is a positive outcome as families with limited resources often have fewer books at home [10]. No other family characteristics had significant differences on children's involvement in language and literacy activities. Parents with limited resources may be more willing to learn and try new skills. Previous family literacy programs have targeted families with limited resources [43] and it has been shown that explicitly teaching parents strategies can help improve intergenerational literacy [44].

\section{Limitations and Future Directions}

Results from this study should be interpreted with some caution. Regardless of the duration of the program and 


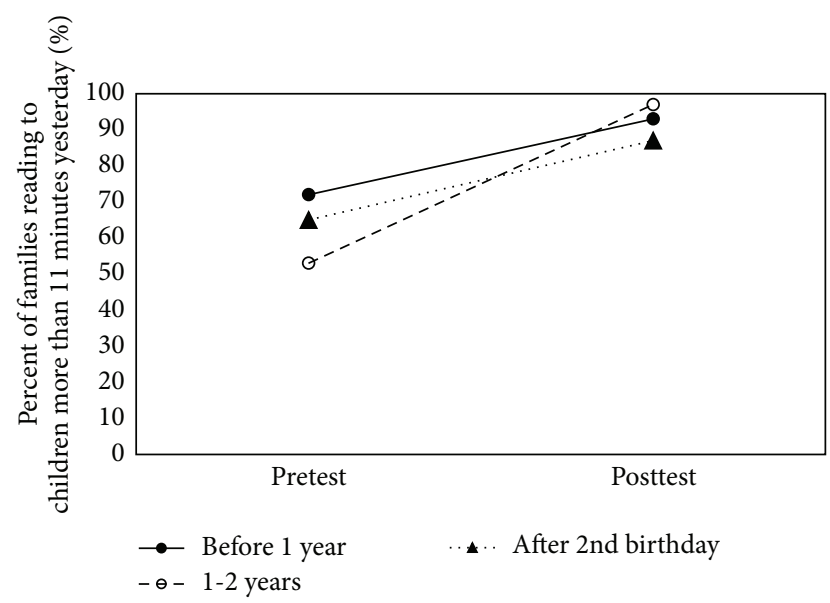

FIGURE 10: Estimated marginal means for percent of families reading to children more than 11 minutes the day before the class between different groups of first time to read to children across time with control of durations.

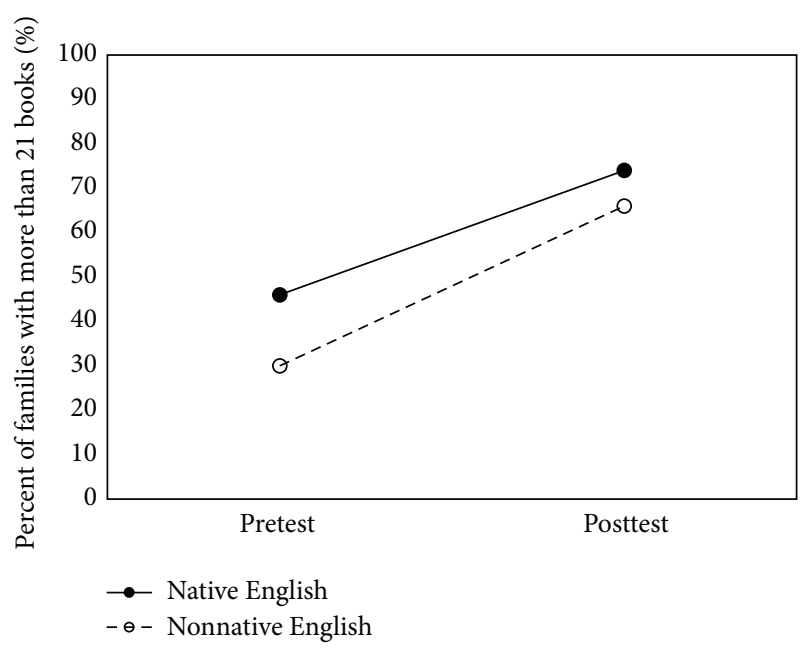

FIGURE 11: Estimated marginal means for percent of families with more than 21 books between different language groups across time with control of durations.

family characteristics, all participants indicated an increase in the frequency of engaging in reading and emergent language/literacy activities. It should be noted that results were based on parent self-reporting. It would be beneficial for future studies to determine family involvement levels based on direct observation of behavior and assess children's language and literacy outcomes. Around sixty percent of participants in the study were of Hispanic ethnicity and from economically disadvantaged areas in a southwestern state, thus limiting generalization of the results. The program was provided in participants' neighborhood schools and child care centers, so participants shared similar characteristics. In this study several family characteristics were examined, not specific neighborhood factors.

Future studies may want to measure in-depth neighborhood factors such as perceived social network [24] to determine its influence on family literacy program outcomes. It is also recommended that researchers examine specific child outcomes such as children's literacy levels. The researchers also did not have a comparison group as this study was conducted as part of the Striving Readers Comprehensive Literacy Program which required the involvement of all eligible participants. In the future, studies with randomized experimental designs would strengthen research findings in this area of study. Additionally, researchers should consider comparing different types of community-based family literacy programs, various neighborhood factors, and the long-term effects and cost-effectiveness of those programs.

\section{Conclusions}

To sum up, both the 6-week and 4-week Family Storyteller Program for Preschoolers were effective in promoting participating families literacy skills; however, there were differences in the types of child and parent outcomes based on program duration and family characteristics. Involving families in language and literacy activities at home is important to preschoolers' development of early literacy skills. Therefore, community-based family literacy programs can be an important jump-start for promoting families engagement in language and literacy at home.

\section{Competing Interests}

The authors declare that they have no competing interests.

\section{References}

[1] G. J. Duncan, C. J. Dowsett, A. Claessens et al., "School readiness and later achievement," Developmental Psychology, vol. 43, no. 6, pp. 1428-1446, 2007.

[2] J. P. Shonkoff and D. A. Phillips, From Neurons to Neighborhoods: The Science of Early Childhood, Development, National Academy Press, Washington, DC, USA, 2000.

[3] National Center for Education Statistics, National Assessment of Adult Literacy: State and County Estimates of Low Literacy, 2013, http://nces.ed.gov/naal.

[4] National Early Literacy Panel, Developing Early Literacy: Report of the National Earl Literacy Panel National Institute for Literacy, Washington, DC, USA, 2013, http://lincs.ed.gov/ publications/pdf/NELPReport09.pdf.

[5] S. Mui and J. Anderson, "At home with the Johars: another look at family literacy," The Reading Teacher, vol. 62, no. 3, pp. 234243, 2008.

[6] V. Purcell-Gates, "Stories, coupons, and the TV Guide: relationships between home literacy experiences and emergent literacy knowledge," Reading Research Quarterly, vol. 31, no. 4, pp. 406428, 1996.

[7] D. Taylor and C. Dorsey-Gaines, Growing Up Literate: Learning from Inner-City Families, Heinemann, Portsmouth, NH, USA, 1988.

[8] A. Waldbart, B. Meyers, and J. Meyers, "Invitations to families in an early literacy support program," Reading Teacher, vol. 59, no. 8, pp. 774-785, 2006.

[9] S.-F. Lam, K. Chow-Yeung, B. P. H. Wong, K. K. Lau, and S. I. Tse, "Involving parents in paired reading with preschoolers: results from a randomized controlled trial," Contemporary Educational Psychology, vol. 38, no. 2, pp. 126-135, 2013. 
[10] N. L. Aikens and O. Barbarin, "Socioeconomic differences in reading trajectories: the contribution of family, neighborhood, and school contexts," Journal of Educational Psychology, vol. 100, no. 2, pp. 235-251, 2008.

[11] D. K. Dickinson and P. O. Tabors, Beginning Literacy with Language: Young Children Learning at Home and School, Brookes Publishing, Baltimore, Md, USA, 2001.

[12] R. G. St. Pierre, A. E. Ricciuti, and T. A. Rimdzius, "Effects of a family literacy program on low-literate children and their parents: findings from an evaluation of the even start family literacy program," Developmental Psychology, vol. 41, no. 6, pp. 953970, 2005.

[13] P. D. Zeece and B. M. Wallace, "Books and good stuff: a strategy for building school to home literacy connections," Early Childhood Education Journal, vol. 37, no. 1, pp. 35-42, 2009.

[14] K. Lawson, "The real power of parental reading aloud: exploring the affective and attentional dimensions," Australian Journal of Education, vol. 56, no. 3, pp. 257-272, 2012.

[15] D. R. Carter, D. J. Chard, and J. L. Pool, "A family strengths approach to early language and literacy development," Early Childhood Education Journal, vol. 36, no. 6, pp. 519-526, 2009.

[16] D. R. Wilson, "Family literacy packs: preservice teachers' experiences with family-school connections," Reading Improvement, vol. 50, no. 1, pp. 30-33, 2013.

[17] K. J. Swick, "Promoting school and life success through early childhood family literacy," Early Childhood Education Journal, vol. 36, no. 5, pp. 403-406, 2009.

[18] P. Hannon, "Family literacy programmes," in Handbook of Early Childhood Literacy Research, N. Hall, J. Larson, and J. Marsh, Eds., Sage, London, UK, 2003.

[19] J. Camilleri, S. Spiteri, and S. Wolfendale, "Parent empowerment for family literacy: a European initiative," Literacy, vol. 39, no. 2, pp. 74-80, 2005.

[20] A. Van Kleeck, "Providing preschool foundations for later reading comprehension: the importance of and ideas for targeting inferencing in storybook-sharing interventions," Psychology in the Schools, vol. 45, no. 7, pp. 627-643, 2008.

[21] J. M. Froiland, D. R. Powell, K. E. Diamond, and S.-H. C. Son, "Neighborhood socioeconomic well-being, home literacy, and early literacy skills of at-risk preschoolers," Psychology in the Schools, vol. 50, no. 8, pp. 755-769, 2013.

[22] U. Bronfenbrenner, "Developmental research, public policy, and the ecology of childhood," Child Development, vol. 45, no. 1, pp. $1-5,1974$.

[23] U. Bronfenbrenner and P. A. Morris, "The ecology of human developmental processes," in The Handbook of Child Psychology, W. Damon and and N. Eisenberg, Eds., John Wiley \& Sons, New York, NY, USA, 1988.

[24] J. M. Froiland, D. R. Powell, and K. E. Diamond, "Relations among neighborhood social networks, home literacy environments, and children's expressive vocabulary in suburban at-risk families," School Psychology International, vol. 35, no. 4, pp. 429444, 2014

[25] D. E. Kohen and V. S. Dhinten, "Neighborhood disadvantage: pathways of effects for young children," Child Development, vol. 79, no. 1, pp. 156-169, 2008.

[26] J. Anderson, N. Friedrich, and J. E. Kim, Implementing a Bilingual Family Literacy Program with Immigrant and Refugee Families: The Case of Parents as Literacy Supporters (PALS), Decoda Literacy Solutions, Vancouver, Canada, 2011.
[27] G. Brooks, K. Pahl, A. Pollard, and F. Rees, Effective and Inclusive Practices in Family Literacy, Language and Numeracy: A Review of Programmes and Practice in the UK and Internationally, CfBT Education Trust, Reading, UK, 2008.

[28] A. Anderson, J. Anderson, and L. Teichert, "Through a rearview mirror: families retrospectively evaluate a family literacy program twenty years later," The School Community Journal, vol. 23, no. 2, pp. 33-53, 2013.

[29] D. J. Besharov, P. Germans, C. A. Higney, and D. M. Call, Even Start Family Literacy Program (3rd National Evaluation), Working Paper 11, University of Maryland, School of Public Policy, Welfare Reform Academy, 2011.

[30] National Center for Families Learning, Meta Analysis of High Performing Family Literacy Programs, 2013, http://familieslearning.org/pdf/TFLPSynthesis.pdf.

[31] A. B. Terlitsky and J. Wilkins, "Characteristics of family literacy programmes that improve child literacy, behaviour and parenting skills," International Journal of Pedagogies and Learning, vol. 10, no. 2, pp. 121-138, 2015.

[32] M. Sénéchal and L. Young, "The effect of family literacy interventions on children's acquisition of reading from kindergarten to grade 3: a meta-analytic review," Review of Educational Research, vol. 78, no. 4, pp. 880-907, 2008.

[33] H. S. Scarborough and W. Dobrich, "On the efficacy of reading to preschoolers," Developmental Review, vol. 14, no. 3, pp. 245302, 1994.

[34] R. van Steensel, N. McElvany, J. Kurvers, and S. Herppich, "How effective are family literacy programs? Results of a meta-analysis," Review of Educational Research, vol. 81, no. 1, pp. 69-96, 2011.

[35] D. K. Dickinson and C. E. Snow, "Interrelationships among prereading and oral language skills in kindergartners from two social classes," Early Childhood Research Quarterly, vol. 2, no. 1, pp. 1-25, 1987.

[36] W. A. Foster and M. Miller, "Development of the literacy achievement gap: a longitudinal study of kindergarten through third grade," Language, Speech, and Hearing Services in Schools, vol. 38, no. 3, pp. 173-181, 2007.

[37] C. S. Puranik, C. J. Lonigan, and Y.-S. Kim, "Contributions of emergent literacy skills to name writing, letter writing, and spelling in preschool children," Early Childhood Research Quarterly, vol. 26, no. 4, pp. 465-474, 2011.

[38] M. A. Restrepo, P. J. Schwanenflugel, J. Blake, S. NeuharthPritchett, S. E. Cramer, and H. P. Ruston, "Performance on the PPVT-III and the EVT: applicability of the measures with African American and European American preschool children," Language, Speech, and Hearing Services in Schools, vol. 37, no. 1, pp. 17-27, 2006.

[39] E. Garcia and B. Jensen, "Early educational opportunities for children of hispanic origins," Social Policy Reports 23-2, Society for Research in Child Development, Ann Arbor, Mich, USA, 2009.

[40] J. Anderson, S. Smythe, and S. J. Shapiro, "Working and learning with families, communities, and schools: a critical case study," in Portraits of Literacies across Families, Communities and Schools: Intersections and Tensions, J. Anderson, M. Kendrick, T. Rogers, and S. Smythe, Eds., Laurence Erlbaum Associates, Mahwah, NJ, UAS, 2005.

[41] D. Weigel, S. Martin, B. Nuygen-O'Massey, and P. Miller, Family Storyteller Child Enrichment Manual, Curriculum Material-0502, University of Nevada Cooperative Extension, Reno, Nev, USA, 2005. 
[42] Y. Xu, C. Chin, E. Reed, and C. Hutchinson, "The effects of a comprehensive early literacy project on Preschoolers' language and literacy skills," Early Childhood Education Journal, vol. 42, no. 5, pp. 295-304, 2014.

[43] P. A. Robinson, "Literacy engagement and parental development through Even Start family literacy participation," Journal of Research and Practice for Adult Literacy, Secondary, and Basic Education, vol. 1, pp. 19-29, 2012.

[44] C. Kagitcibasi, D. Sunar, S. Bekman, N. Baydar, and Z. Cemalcilar, "Continuing effects of early enrichment in adult life: the Turkish early enrichment project 22 years later," Journal of Applied Developmental Psychology, vol. 30, no. 6, pp. 764-779, 2009. 


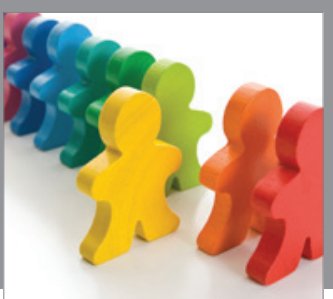

Autism

Research and Treatment
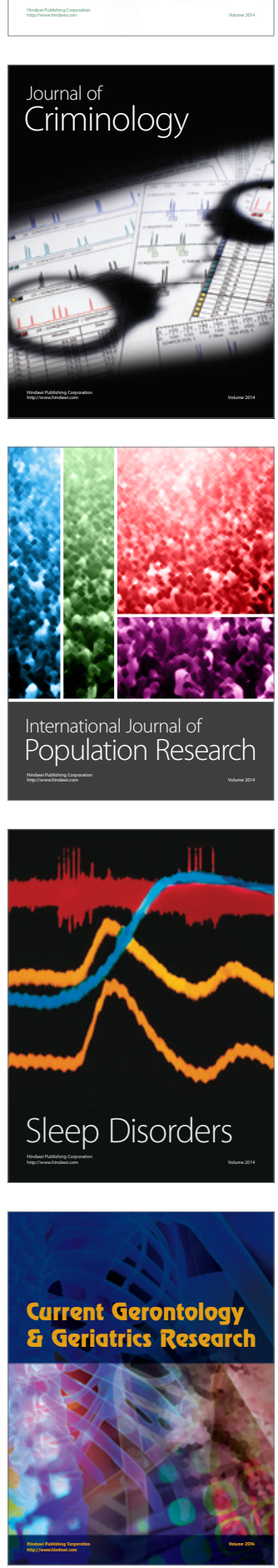

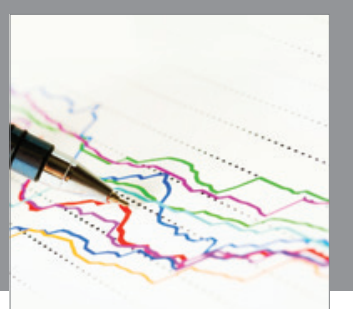

Economics

Research International
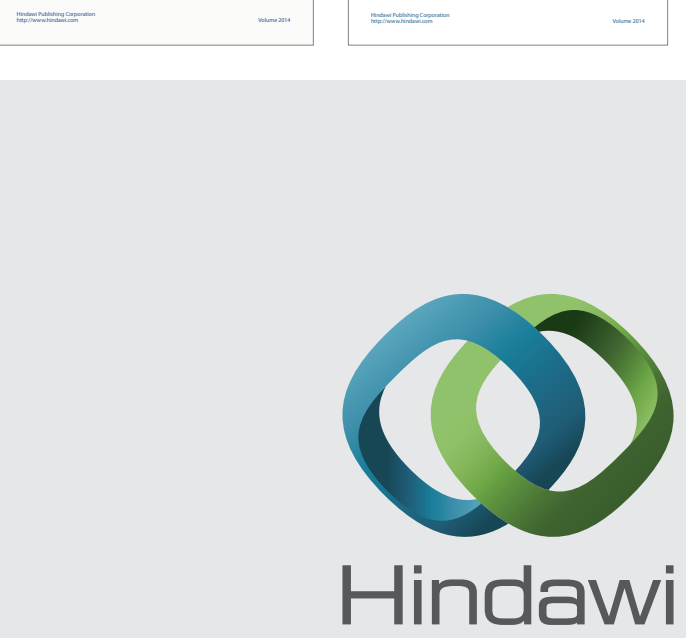

Submit your manuscripts at

http://www.hindawi.com
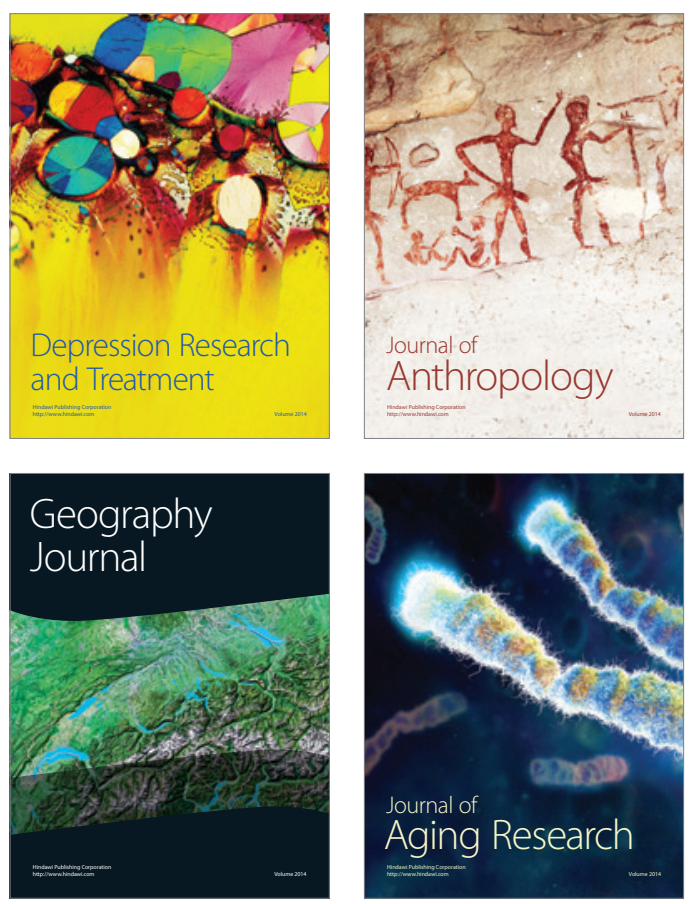
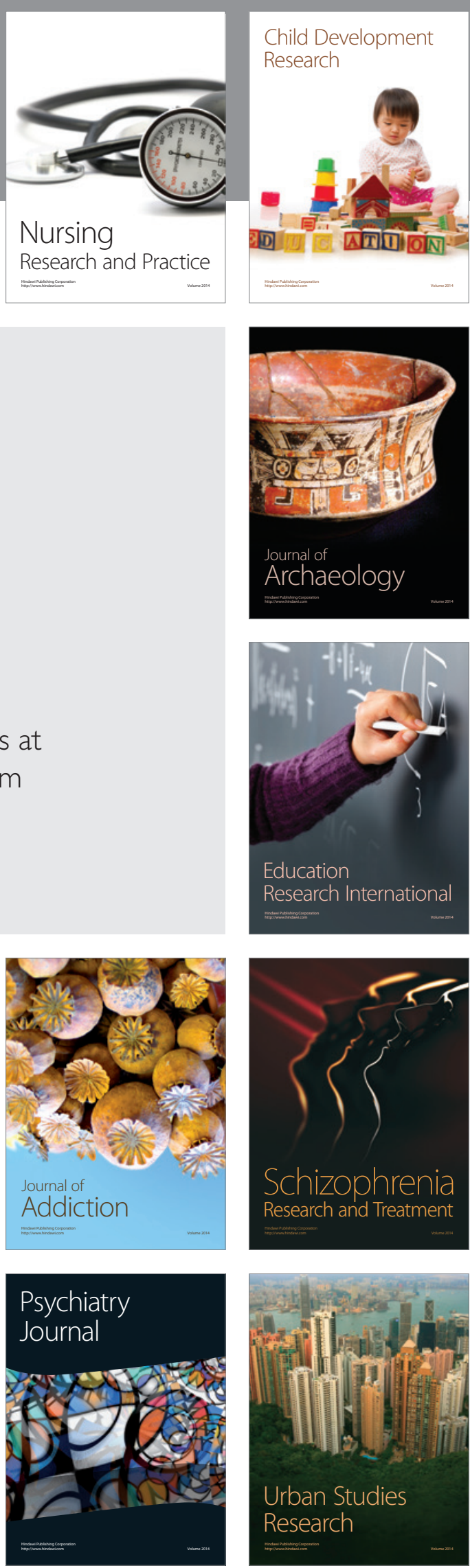